DOI - https://doi.org/10.5965/2316796309182020003

\title{
Ergonomic and Biomechanical Analysis of the Manioc Root Harvest: Case Report
}

\author{
Lincoln Silva $^{1}$ \\ Eugenio Merino ${ }^{2}$ \\ Diego Mattos 3 \\ Bruno Maia de Guimarães ${ }^{4}$ \\ Noé Borges Junior ${ }^{5}$ \\ Susana Domenech ${ }^{6}$ \\ Giselle Merino ${ }^{7}$
}




\begin{abstract}
The aim of this case report was to evaluate the risks of musculoskeletal injuries from manual extraction of manioc roots in a Brazilian family farming production. It was used a lumbar extension isometric dynamometry, electromyography and infrared thermography of the surface at the back of the worker and the whole collection of data was made in loco. The results showed an increased temperature on the surface of the left lower back $\left(+0.6^{\circ} \mathrm{C}\right)$, the values of isometric strength upon lumbar extension (143 $\pm 2.66 \mathrm{Kgf})$ and electromyography alteration in the muscles. The questionnaires indicate that the individual complains of discomfort along all of the back of his torso. The activity of manioc manual extraction can generate an overload on the lumbar and shoulder girdle muscles. It can affect the individual productive state.
\end{abstract}

Key-words: Family agriculture; Manioc; Ergonomics; Biomechanics; Musculoskeletal Disorders.

\footnotetext{
${ }^{1}$ Mestre - UFSC (lincolnsilvafisio@gmail.com)

2 Doutor - UFSC (eugenio.merino@ufsc.br)

3 Doutor - UFSC (diegoclerigo@yahoo.com.br)

${ }^{4}$ Doutor - IFC (bmguimaraes@hotmail.com)

${ }^{5}$ Doutor - UDESC (noe.borges@udesc.br)

6 Doutora - UDESC (d2scd@udesc.br)

7 Doutora - UFSC (gisellemerino@gmail.com)
} 


\section{Introduction}

Manioc (Manihot esculenta Crantz) is a tropical and widely grown crop and it makes the basic energy nourishment for over 800 million people in the world (FAO, 2013). In the harvest of 2015, Brazil produced around 22.7 million tons, which was $8 \%$ of the production in the world, in a total area of 1.494 .498 .00 acres of plantation yielding 15.227 tons/acre ( CONAB, 2016; IBGE, 2016).

With around 27 thousand acres of crops and yearly production of 500 thousand tons, the state of Santa Catarina remains as the 12th major national producer of manioc, but is the 5th state in productivity achieving 18.5 tons per acre (EPAGRI, 2015).

Despite the high production of this crop, few studies have been accomplished for an improvement of production systems and, consequently, of activities that require a major physical effort by the laborers and which often lead to incapacity for work (Fernandes et al., 2013; Fernandes, et al., 2014; Cunha, Merino and Merino, 2015). It is important to highlight that, although such activity can be made in a mechanic or automated manner, it is mainly made manually. In general, the musculoskeletal disorders are the most common and most expensive pathologies in agriculture (Fathallah, Miller and Miles, 2008; Kirkhorn, Earle-Richardson, and Banks, 2010; Fathallah, 2010; Merino et al. 2019), and can lead to absenteeism.

As the extraction of manioc roots is a manual activity that requires the use of the upper and lower body and also the torso for the extraction of the root by the laborers, there is the need for measuring its impact in relation to health when laboring. It can be noticed that few studies present information about the physical consequences of this activities in the short and in the long term. The activity of manually extracting manioc roots, in this way, needs a broader understanding concerning its effect on the worker, by means of analysis of qualitative and quantitative data.

The conditions of work for the man in the countryside which can lead to the laborer's getting ill and going off his work for injuries of musculoskeletal nature, indicate a gap of knowledge that requires an understanding of the physical consequences of this rural work.

This research had for purpose to evaluate the risks of musculoskeletal disorders from the activities of manioc roots extraction, with appropriate technological evaluation instruments, namely: isokinetic dynamometry of lumbar extension (IDLE), electromyography (EMG) and, complementing the data, thermography prior to the activity.

\section{Materials and Methods}

This research is applied in nature, with a quantitative and qualitative approach, descriptive, and of exploratory nature. The collection of data was carried out with the use of anthropometric information, characteristics of the activities carried out by the researched individual were surveyed, Nordic questionnaire for the analysis of musculoskeletal symptoms, infrared skin thermography, IDLE and EMG of the multifidus muscles (right and left) and upper trapezium (right and left). All of the information was captured in loco.

The sample was composed of a Family agriculture laborer, male gender, who carries out the stage of manual extraction of manioc roots in the property. The choice criteria happened because of the activities carried out in the property of the laborer 
under study. The sample is justified because, within the context of the study, families where a couple looks after the property is a common practice where the man is responsible for the outdoors activities that require physical strength, and the woman is responsible for the indoors chores that are less demanding physically.

The research was approved by the Ethics on Research Committee of the Federal University of Santa Catarina under ruling nr 05372012.9.0000.0121. The participant signed the Voluntary Informed Consent (TCLE).

\subsection{Characterizing the Individual and Describing the Activity}

To characterize the individual anthropometric measurements of body mass and stature were made as well as the Nordic questionnaire, in order to describe the points with body ache (Kuorinka, 1987).

To describe the activity, there was observation, and videoing with a GoPro Hero 3 Black Edition ${ }^{\circledR}$ camera, at the place where the manioc roots are cropped. During harvest the farmer filled three scales based on the 0 to 10 Borg scale (BORG, 1988), related to the themes: Effort, Discomfort and Usability. The following questions were made to the laborer, respectively: How much effort do you use to pull the manioc roots out, where 0 means no effort and 10 means maximum effort; How much discomfort do you feel while you manually pull the manioc roots out, where 0 means no effort and 10 means maximum effort; How easy is it for you to pull the manioc roots out with your hands, where 0 means no usability and 10 means maximum usability or ease to carry out the task. The last question was based on the concepts of usability proposed by Jordan (1998) and Nielsen (2007) who describe those as being the easiness, comfort and safety on handling a product or carrying out a certain task.

\subsection{Thermography}

To collect the infrared images (IR), an infrared FLIR® camera, model E-40 was used. For the collection of images, after a period of 2 hours with no vigorous physical activities, the subject under study remained with no shirt on, in an orthostatic posture, one meter away from the thermo vision, arms stretched and relaxed alongside the body on a smooth surface and having no contact with sunlight (Brioschi, Macedo and Macedo, 2003) . Images were collected of the shoulder girdle and lumbar spine region. The room temperature remained at $200 \mathrm{C}$ during all the time of collection.

For an analysis of skin temperature, rectangular homolateral areas were selected at the lumbar spine and shoulder girdle areas, over the muscles of the abdomen where the EMG electrodes would be placed and an average of the points in each triangle was calculated.

Thermography was carried out only in the period prior to the practice of the physical activity with the purpose of checking of checking for possible hyperthermia regions showing the occurrence of inflammatory process and/or tissue alteration on course in the regions where the electromyography electrodes would be placed.

\subsection{Isometric Dynamometry of the lumbar back (IDLE)}

Dynamometry is the most used instrumentation for the valuation of isometric muscular strength. It can demonstrate the variation of strength along time (Borges 
Junior, 2009). At IDLE, the individual was barefoot, placed upon the platform containing a cell of " $S$ " charge (maximum capacity of $200 \mathrm{~N}$ ) attached and connected to the data acquisition system Miotool 400 by Miotec. He remained with his back straight keeping his arms stretched in front of his thighs in order to make the correct posture for the handle that was to be pulled. Next, the individual was asked to perform the forward bending of the torso (around 1400), a slight bending of his knees, and holding the handle with his hands he was asked to pull it with his utmost strength in a way that it was perpendicular with the platform, with no contact between the handle or his hands and any other part of his body (Figure 1). The maximum values were collected from three attempts in order to make the arithmetic average of the test (Silva, 2015; Da Veiga, 2018).

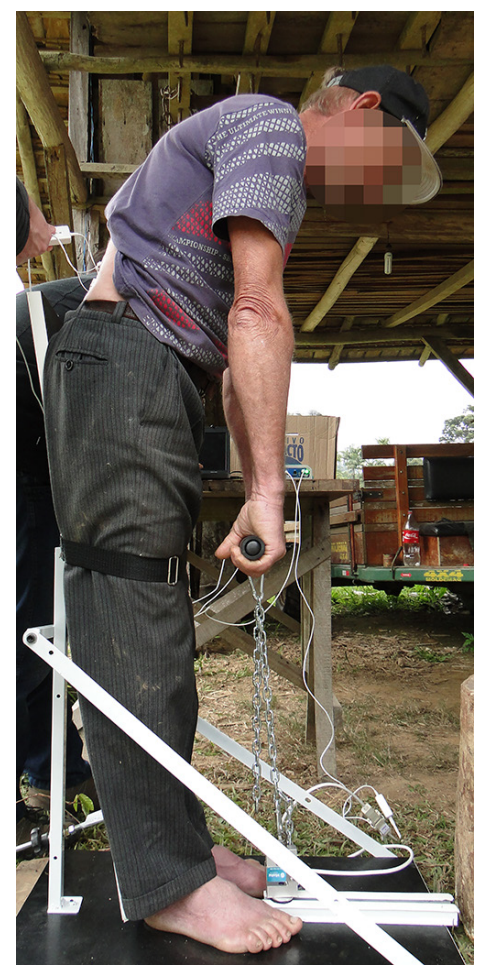

\subsection{Electromyography (EMG)}

The acquisition of electromyography signs (EMG) was accomplished with a 4 channel Miotool 400 electromyography by Miotec. The system works with the software Miograph 2.0 USB, where the data are transmitted to a portable computer. The signs of strength and EMG were collected with a sample rate of $1000 \mathrm{~Hz}$ for each channel, high pass filter of $5 \mathrm{~Hz}$, low pass filter of $500 \mathrm{~Hz}$ and notch filter $60 \mathrm{~Hz}$.

For the registration of electromyography signs, pairs of $\mathrm{Ag} / \mathrm{AgCl}$ surface electrodes were used, pre-jellied (Meditrace $®$ ), in bipolar configuration, with a capture area of $1 \mathrm{~cm}$ diameter and a distance of $2 \mathrm{~cm}$ between electrodes, with fixative adhesive. The electrodes were positioned on the multifidus right and left muscles at the level of the lumbar vertebrae L4-L5 and upper portion trapezium (TS) bilaterally (Barbosa, Almeida e Gonçalves, 2010), according to the rules by SENIAM (2002). The reference electrode was placed at the Sacrum, to allow mobility of upper limbs throughout the test. All of the rules relating to the adequate registration of EMG signs were observed, as 
recommended by the International Society of Electrophysiology and Kinesiology (ISEK) (Merletti, 2000). Before the electrodes were put in place the following procedures were carried out: (1) identification of the points where electrodes should be placed, (2) skin tricotomy and abrasion with gauze, (3) hygiene with 70\% alcohol, (4) placement of electrodes at previously prepared regions (Moraes, 2003; O'sullivan e Schmitz, 2004) To normalize the EMG and obtain Maximum Voluntary Isometric Contraction (MVIC) at isometric strength of lumbar traction, three tests, with 10 seconds resistance maintenance and with 2 minute interval between the acquisitions, were carried out. For that, the subject under study was positioned in orthostatic posture with hip bending at around $140^{\circ}$, simulating the gripping position to pull the manioc root out of the ground. In relation to the upper left and right trapezium, the subject remained seated maintaining his upper limbs relaxed along his body for around 30 seconds before the test. Next, resistance to his elbow was imposed with his shoulder at $90^{\circ}$ abduction with simultaneous resistance to the head extension after the neck was bent to the same side and turned to the opposite side. Three tests were done where 5 minutes resistance was maintained and an interval of 5 seconds between the acquisitions was kept (Ekstrom, Soderberg e Donatelli, 2005).

Muscular fatigue was identified by observing the diminution of Median Frequency (MF) values concomitantly to an increase of electromyography sign (Root mean square) RMS.

After the maximum isometric strength test, the participant remained over 10 minutes without strength activity. After this period of rest, the activity of manually extracting manioc roots was carried out.

The activity of manually extracting manioc roots monitored by EMG lasted 20 minutes, although it was only possible to get a good quality electromyography sign for 2 minutes and 40 seconds. Such occurred because the collection of data was carried out in a real work situation. The selected period of electromyography sign was divided into 16 intervals of 10 seconds each, when electromyography peaks were observed by means of the root mean square - RMS $(\mu \mathrm{V})$ and the MF $(\mathrm{Hz})$.

\section{Results}

\subsection{Characterizing the Individual and Describing the Activity}

The subject of this research is 53 years old, $1.70 \mathrm{~m}$ tall, and body mass of $65 \mathrm{~kg}$. Although he had a short experience in industry he has always been linked to family agriculture. Two hundred kilograms of manioc are extracted weekly and he works twice a week, four hours each time, to achieve this production amount. Figure 02 below shows the complains of pain based on the Nordic questionnaire, level of effort, discomfort and usability, according to the Likert scale and the posture adopted to pull out the manioc root. 

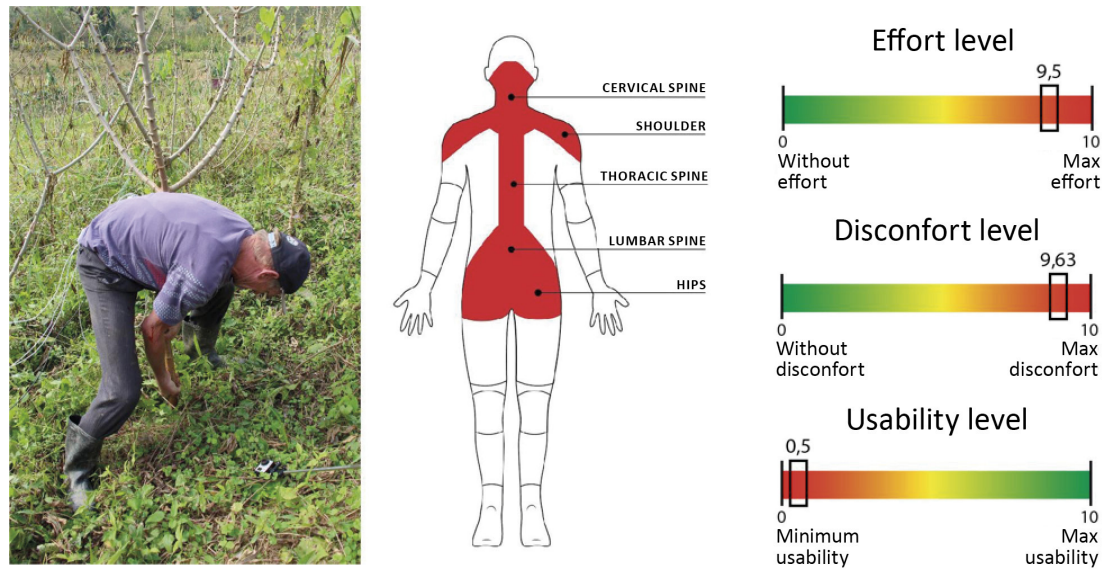

\subsection{Thermography}

Next, images of superficial body temperature on the lumbar spine and shoulder girdle areas are shown (Figure 3) where there was difference, with an increase in superficial temperature before the activity in the left lumbar area.

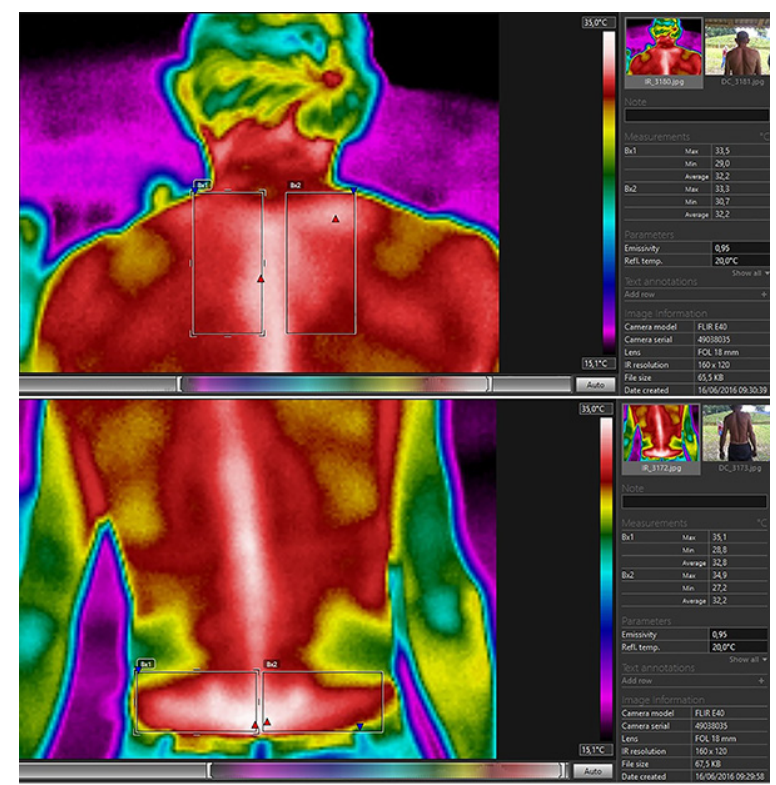

The average temperature in the proposed rectangular areas was presented according to table 1 .

Table 1 Average temperature in the lumbar and shoulder girdle areas

\begin{tabular}{lcc}
\hline & Right & Left \\
\hline Lumbar Area & 32.2 & $32.8^{*}$ \\
Shoulder Girdle & 32.2 & 32.2 \\
\hline
\end{tabular}

Source: The authors, 2017.

HFD, v.9, n 18, p. 03-19, dezembro 2020 


\subsection{Isometric Dynamometry of the Lumbar Back (IDLE)}

The results obtained by means of dynamometry allowed to identify that, with regards to the peak and isometric strength average of the lumbar back, there was a greater difference between values found in collections 1 and 2 than the ones found in collections 2 and 3 . The greatest strength peak happened in the second collection, while the greatest average was found in the third collection (Table 2).

Table 2: Peak and average of isometric force in the lumbar back (kgf).

\begin{tabular}{lcccc}
\hline & $\begin{array}{c}\text { Collection 1 } \\
\text { (kgf) }\end{array}$ & $\begin{array}{c}\text { Collection 2 } \\
\text { (kgf) }\end{array}$ & $\begin{array}{c}\text { Collection 3 } \\
\text { (kgf) }\end{array}$ & $\begin{array}{c}\text { Average } \pm \\
\text { Standard } \\
\text { Deviation (DP) }\end{array}$ \\
\hline Peak of Force & 133 & 150 & 146 & $143 \pm 8.9$ \\
Average Force & 113 & 124 & 126 & $121 \pm 6.8$ \\
\hline
\end{tabular}

Source: The authors, 2017.

\subsection{Electromyography (EMG)}

The figure 4 shows, by electromyography sign- RMD, the production of strength at the right multifidus and its fatigue derived from the length of time of the performance, by MF, on the manual extraction of manioc. The line showing the drop tendency of the MF values and the respective linear equation are also represented. The tendency for a loss of strength and settlement of fatigue can be highlighted especially at the (5060) moment when there was an increased electromyography sign- RMS (177 $\mu \mathrm{V})$ and concomitant decrease of MF $(91 \mathrm{~Hz})$ values.

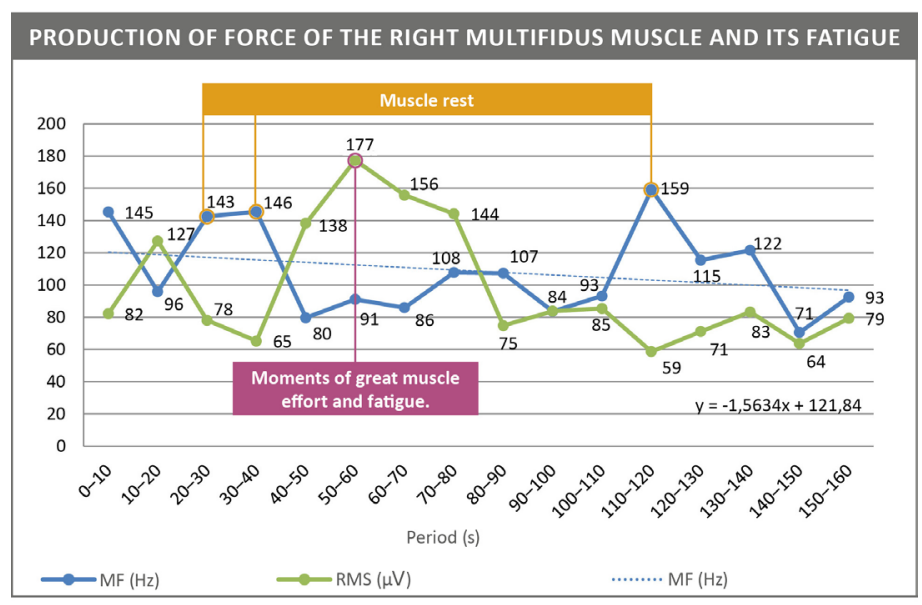

Figure 5 presents the production of strength at the left multifidus muscle, by electromyography sign- RMD, and its fatigue derived from the length of time of the performance, by MF. The line showing the drop tendency of the MF values and the respective linear equation are also represented. The tendency for a loss of strength and 
settlement of fatigue can be highlighted especially at the [(60 - 70); (90-100); (110-120) e 150-160)] moment when there was an increased electromyography sign- RMS and concomitant decrease of MF values.

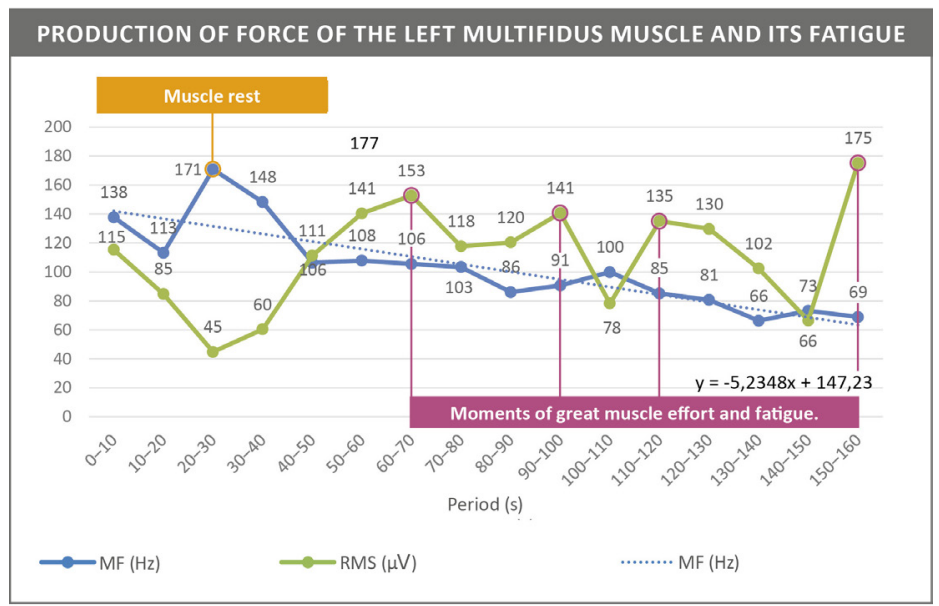

When figure 4 and 5 are compared, it can be said that more fatigue settled onto the left multifidus muscle, with little recovery of MF due to time on that side.

Figure 6 shows the average percent of effort, in periods of 10 seconds each, of the multifidus muscles, normalized by the average of maximum electromyography activity obtained on the maximum voluntary isometric contraction test (MVIC) (Right Multifidus: $300,5 \mu \mathrm{V}$ and Left Multifidus: $294,04 \mu \mathrm{V}$ ). The left multifidus was observed to show higher average values (54\%) when compared to the right multifidus (47\%) thus showing a greater left paravertebral activity for sustaining the bending and stretching movements of the torso.

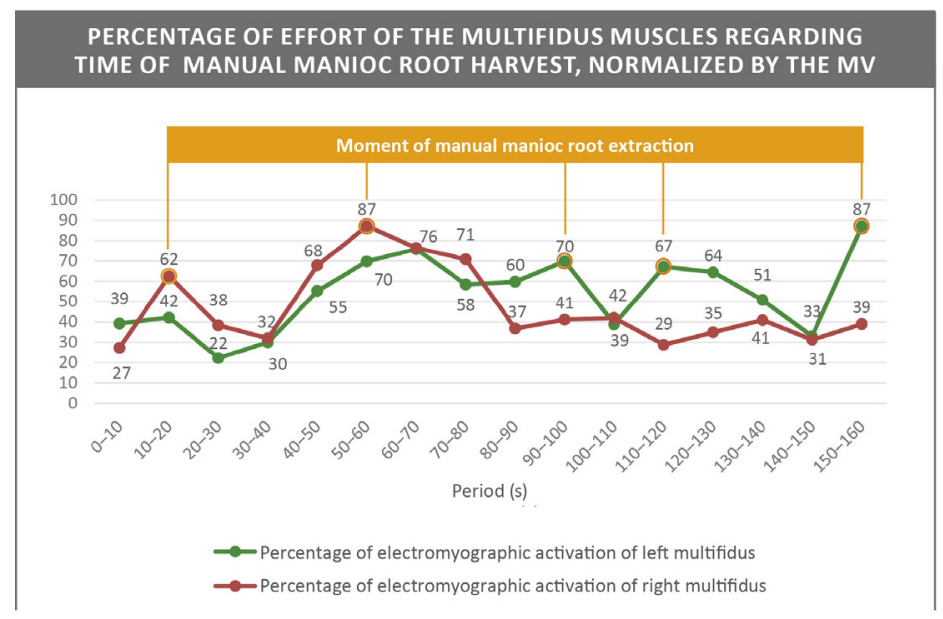

Regarding the trapezium muscles, in their upper portions, Figure 7 shows the electromyography data of RMS and MF to the right side and its fatigue according to the time taken by the labor activity. The line showing the drop tendency of the MF values and the respective linear equation are also represented. The tendency for a loss of strength and settlement of fatigue can be highlighted especially at the [(60 - 70); (90- 
100); (110-120) and 150-160)] moment when there was an increased electromyography sign- RMS and concomitant decrease of MF values.

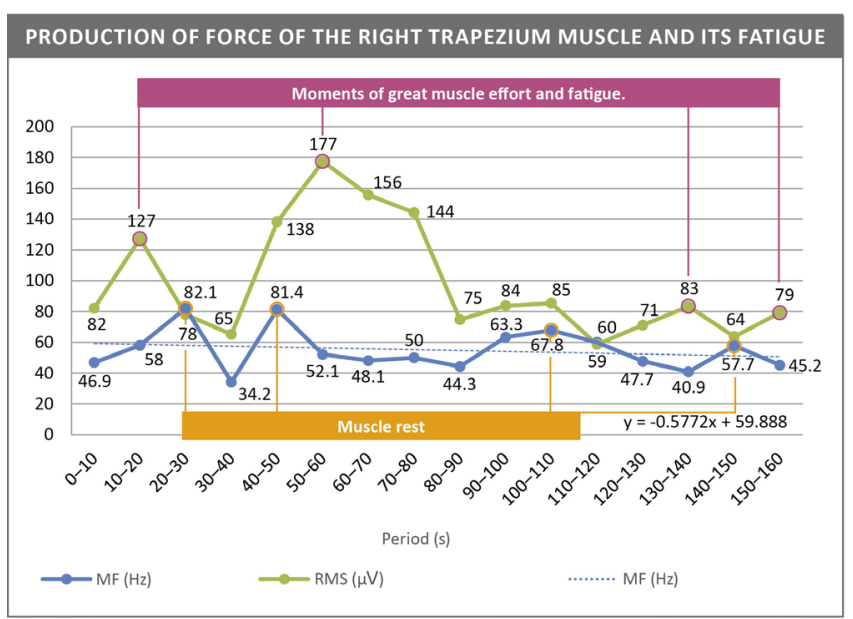

Figure 8 presents the RMS and MF electromyography data of the left trapezium and its fatigue in relation to the time on the activity. Likewise, the line showing the drop tendency of the MF values and the respective linear equation are also represented. The tendency for a loss of strength and settlement of fatigue can be highlighted especially at the [(60 - 70); (90-100); (110-120) and 150-160)] moment when there was an increased electromyography sign- RMS and concomitant decrease of MF values.

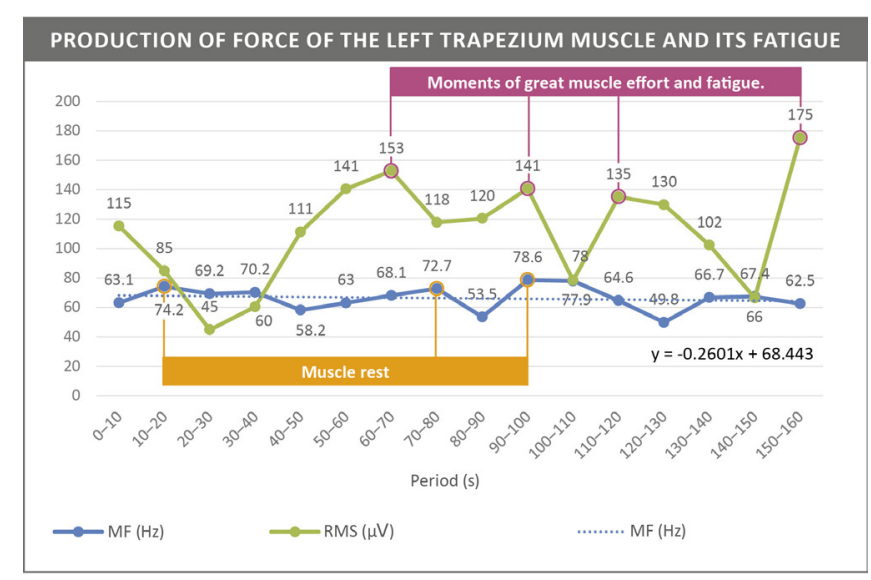

Upon comparing figures 7 and 8 , it can be said that fatigue settled more considerably on the upper fibers of the right trapezium muscle, and there was little recovery of the MF due to the time on that side. Between moments (30-40) and (80-90) there was an important overload and triggered fatigue on both sides.

Figure 9 shows the average of the effort percentage of the fibers in the upper right and left trapezium, in periods of 10 seconds, normalized by the average of the maximum value of electromyography activities obtained at MVIC test (Right Trapezium: $1065,7 \mu \mathrm{V}$ and Left Trapezium: 1089 $\mu \mathrm{V})$. The right trapezium muscle was observed to show an average of the higher values (20\%) when compared to the left (14\%) thus demonstrating a higher effort on the right side, which can be related to dominance of the limbs. 


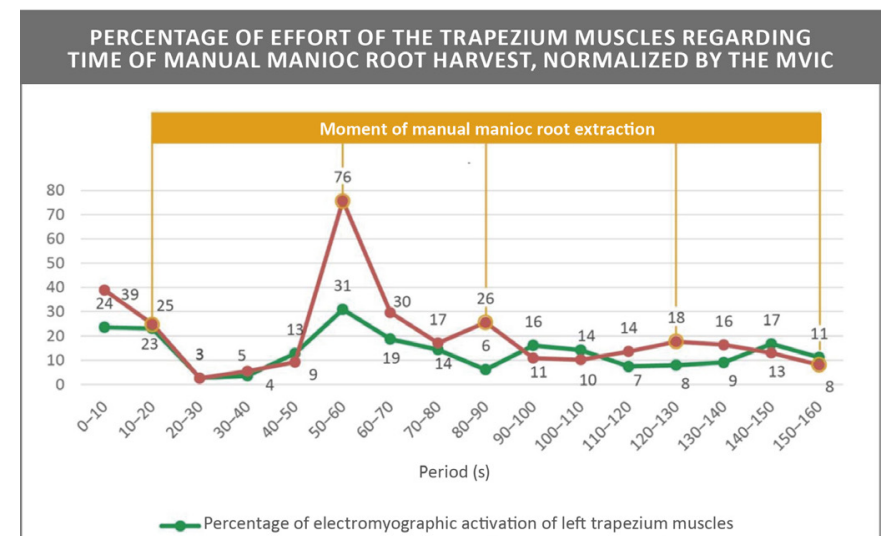

Figure 10 presents a comparison related to the decrease rate of MF related to the time of 10 seconds by means of linear equations shown in charts $01,02,04$ and 05 . An important overload is observed in relation to the shoulder girdle. However, there was a progressive drop of MF on all four muscles observed.

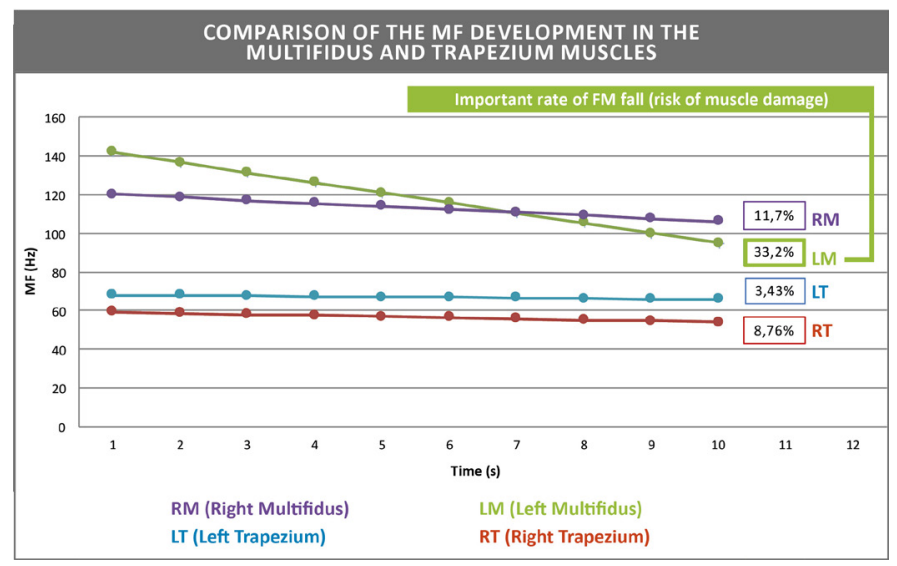

\section{Discussion}

At the rural property where this research was carried out, all of the laboring activities are done by the couple, where the man is responsible for the production of manioc, from planting, handling and cultivation up to the manual extraction of the roots, and his responsibilities are related to the need this production has for great physical effort. Thus, the rural establishment under study is an example of what most properties dedicated to the production of manioc in the country are like: family agriculture, where the landowners are responsible for stages of production in general and don ' $t$ rely on external workforce for the activities to be performed (Fernandes et al., 2014).

In the pre-activity context, through thermography, it was noticed that there was difference in temperature between the multifidus, and the left side showed higher temperature $0.6^{\circ} \mathrm{C}$. According to Andrade Filho (1999), painful conditions from inflammatory, neurogenic or infectious cause generate neurogenic inflammation and liberate chemical substances (neuropeptide) in nerve endings of capillary endothelium, with the production and release of nitric oxide which leads to intense vasodilation and, consequently, a significant increase of infrared emissivity (hyperthermia). 
It was found that, in order to manually extract the manioc roots from a standing up position, the laborer bends his torso, holds the manioc branch and strongly pulls it upwards in order to extract the manioc root from the ground. This manner of extracting the manioc root from the ground is similar to the one found in the research by Cunha, Merino and Merino (2015) and can generate osteomuscular overload on the laborer's shoulders, for according to Costa and Vieira (2009) and Gallagher and Heberger (2013), the high level of strength employed by the shoulders during the task is a risk factor for musculoskeletal injuries on the shoulders. Besides, this activity can also generate risk of musculoskeletal injury on the lumbar spine, since researches have been showing an increase regarding overload on lumbar spine while the torso is bending (Gallagher, et al., 2005; Costa e Vieira, 2009; Prairie et al., 2016) and when strength is being employed by the lumbar spine (Gallagher and Marras, 2012; Stambolian, Eltoukhy and Asfour, 2016).

Such findings are corroborated by the results obtained with an EMG of the superior multifidus and trapezium muscles. In the lumbar spine area, there was a fatigue tendency of the multifidus muscles, especially on the left side. Such situation can happen due to deconditioning provoked by pain and to change in physiological characteristics of multifidus muscles, which end up with diminished amount of type II fiber (Sparto, 1997).

However, maximum isometric strength values of the lumbar spine extension found in this study (143 $\pm 8,9 \mathrm{Kgf})$ are superior to the ones found by Eichinger et al. (2016), in which for healthy males, the average of isometric strength peak of the lumbar spine extension was of $107 \pm 24 \mathrm{Kgf}$, and da Veiga Leonardi, Niltiane, et al (2018) who obtained values of $119 \pm 29,56$ Kgf for males farmers.

A cohort study involving around 1800 workers indicated that drop of strength at the lumbar spine predicted pain in that region to the detriment of the amount of strength produced by it (Reenen and Hamberg-Van, 2006). Such fact corroborates the findings related to the individual under study, who presented important fatigue of the lumbar spine extension muscles with pain in that region, but an amount of strength above the values pointed out in literature.

Regarding the trapezium muscle, electromyography also pointed out muscle fatigue that can be related to the individual's activity, exposed by a drop in median frequency and concomitant to an increase of RMS.

According to Murofuse and Marziale (2005), the trapezium is among those muscles that are most prone to suffer injury for repetitive effort. Harbourne and Kamm (2015) corroborates this statement when he says that shoulders and upper limbs are the ones most susceptible to developing musculoskeletal illness from repetitive muscles.

To Chowdhury et al. (2013) excessive use of muscles, nerves and joints lead to muscle fatigue which is responsible for the majority of inflammatory process in the neck areas. Comel et al. (2014) adds that fatigue can change neuromuscular coordination and can bring vulnerability to musculoskeletal injuries.

In the fields of occupational health and ergonomics, according to Luttmann (2000), the indication of muscular fatigue is necessary once activities inducing muscular fatigue can be performed for a certain time limit. Barbe and Barr (2006) report that several clinical and experimental studies point out that tissue micro trauma occurs as a consequence of repetitive movement or of tasks that require strength, and such mechanical tissue injuries brings along local inflammation and, perhaps, systemic, followed by fibrotic and structural alterations of the tissue. 


\section{Conclusions}

As shown in this study, there is an increase in RMS and diminution of MF frequency during isometric contractions that were evaluated by EMG, indicating an elevation of neuromuscular activation and beginning of fatigue. It indicates that new muscular fibers are recruited without time of recovery, whereas the decrease of MF shows diminution of conduction speed in the action potential from the build-up of metabolic products related to the muscular fatigue (Barbosa and Gonçalves, 2007; Bassani et al., 2008; Candotti et al, 2009; Santana, 2014). Another important factor, related to the evaluation carried out in this study, is that labor activities that require great effort, above $60 \%$ of MVIC, can prevent blood from entering the muscle, generating injuries and adaptations that bring repercussions on the process of sharp fatigue (Roy, De Luca and Casavant, 1989; Larivière et al, 2003; Kramer et al, 2005).

Thus, even if the evaluated subject can maintain the isometric strength of the lumbar spine in normal standards, the electromyography study of multifidus muscles showed that there are physiological alterations already and sharp settlement of fatigue, especially on the left side. Such fact coincided with an increased superficial temperature of the skin on the same side, which was shown on the thermography evaluation prior to the root-pulling activity.

The trapezium regions did not present any differences in temperature averages, but they too presented important settlement of fatigue, which can generate tissue adaptations and the settlement of musculoskeletal disease.

In the shoulder girdle area as much as in the lumbar spine complains of ache were brought about, which can be a sign of musculoskeletal overload shown in this activity. These tissue alterations can generate irreversible damage that would affect the productive state of the individual. As a consequence, the manioc production in a region that depends on family agriculture, with few people involved in the production process, can be compromised and influenced by the ergonomics and biomechanical factors presented in this study.

Having said that, an important contribution of this work concerns the understanding of the risk of disease for the laborer performing such activity. Those risks can directly affect his productive capacity and consequently risk his own survival and that of his family because of the way this production system is practiced.

Likewise, this study fills a gap of knowledge about this activity and, at the same time, it awakens interest for further studies related to this matter in order to bring increasingly more understanding over the impact of such practice.

The methodology used for this work showed itself as satisfactory, and another contribution of this study finds itself in integrating objective and subjective measures regarding the collection of information about the theme, supplying a systemic diagnostic in detriment of specific values or aspects that are only qualitative. In this way, according to Merino et al (2019) research conducted in real work situations shows greater sensitivity to the needs of the workers involved with this activity, making it possible to design recommendations to improve the process as a whole, reducing negative impacts on the worker.

With the purpose to diminish musculoskeletal overload and the level of discomfort upon carrying out the activity, apart from improving usability making work easier for the family farmer laboring on the production of manioc, options are suggested such 
as the development of tools and new planting methods that reduce the physical effort needed at the moment of pulling out the manioc root.

\section{Acknowledgements}

This study was financed in part by the Coordenação de Aperfeiçoamento de Pessoal de Nível Superior - Brasil (CAPES) - Finance Code 001, the National Council for Scientific and Technological Development (CNPq), the Research and Continuing Education Support Foundation (FAPEU), the Research and Development of Assistive Technology Network (RPDTA), the Santa Catarina Agricultural Research and Rural Extension Enterprise (EPAGRI), the Instrumentation Laboratory CEFID-UDESC (LABIN) and the Center for Design Management and the Universal Design Laboratory of the Federal University of Santa Catarina NGD-LDU/UFSC that made this research possible.

\section{REFERENCES}

ANDRADE FILHO,A.C.C.Teletermografia:princípiosfísicos, fisiológicosefisiopatológicos da produção da imagem e suas indicações na clínica de dor e reabilitação. Acta Fisiátrica. v. 6, n. 2, p. 55-59, 1999.

BARBE, M. F., BARR, A. E. Inflammation and the pathophysiology of work-related musculoskeletal disorders. Brain Behav Immun. v. 20, n. 5, p. 423-429, 2006.

BARBOSA, F. S. S., GONÇALVES, M. A biomechamical approach for assessment of overload on lumbar spine: the effects of different demographic variables on muscle fatigue. Acta Ortop Bras. v. 15, n. 3, p. 132-137, 2007.

BARBOSA, F. S. S., ALMEIDA, C. C. R., GONÇALVES, M. Spectral analysis of the electromyographic signal of the erector spinae muscle obtained from Sorensen test. Physical Therapy in Moviment. V. 23, n. 4, p. 575-583, 2010.

BASSANI, E., CANDOTTI, C. T., PASINI, M., MELO, M., LA TORRE, M. Avaliação da ativação neuromuscular em indivíduos com escoliose através da eletromiografia de Superfície. Rev. bras. fisioter. V. 12, n. 1, p. 13-19, 2008.

BORG, G. Borg's Perceived Exertion and Pain Scales. Human Kinetics, Champaign, 1998. BORGES JUNIOR, N. G. B., DOMENECH, S. C., SILVA, A. C. K., DIAS, J. A., SAGAWA JÚNIOR, Y. Estudo comparativo da força de preensão isométrica máxima em diferentes modalidades esportivas. Revista Brasileira Cineantopometria e Desempenho Humano, v.11, p. 292-298, 2009.

BRIOSCHI, M. L., MACEDO, J. F., MACEDO, R. A. C. Termometria cutânea: novos conceitos. J Vasc Bras., v. 2, p. 151-160, 2003.

CANDOTTI, C. T., LOSS, J. F., LA TORRE, M., MELO, M. O., ARAÚJO, L. D., MARCKS, V. V. 
Use of electromyography to assess pain in the upper trapezius and lower back muscles within a fatigue protocol. Rev. bras. fisioter. V. 3, n. 2, p. 144-151, 2009.

CHOWDHURY, S., NIMBARTE, A. D., JARIDI, M., CREESE, R. C. Discrete wavelet transform analysis of surface electromyography for the fatigue assessment of neck and shoulder muscles. Journal of Electromyography and Kinesiology. v. 23, n. 5, p. 995- 1003, 2013.

COMEL, J. C., JUNIOR, J. P. B., CHINI, E. P., PEREIRA, H. M., CARREGARO, R. L.C ., CARDOSO, J. R. Comparison of the electrical activity in upper trapezius and wrist extensor muscles during two typewriting conditions. Physical Therapy in Moviment. V. 27, .n 2, p. 271- 279, 2014.

CONAB - Companhia Nacional de Abastecimento. Conjuntura trimestral - Conjuntura Pernambuco. Brasília-DF, 2016. Available at: http://www.conab.gov.br/OlalaCMS/ uploads/arquivos/16_07_26_17_19_26_mandioca_-_jun_2016_-_sureg_pe.pdf

COSTA, B. R., VIEIRA, E. R. Risk Factors for Work-Related Musculoskeletal Disorders: A Systematic Review of Recent Longitudinal Studies. American Journal of Industrial Medicine. v. 53, n. 3, p. 285-323, 2009.

CUNHA, J. M., MERINO, G. S. A. D., MERINO, E. A. D. Avaliação ergonômica da extração manual de raízes de mandioca em propriedades agrícolas familiares a partir do rastreamento de movimentos 3D (X-Sens). Estudos em Design. V. 23, n. 3, p. 60-72, 2015. DA VEIGA, Leonardi Niltiane, et al. Perfil da musculatura extensora lombar de trabalhadores rurais na atividade leiteira. Revista Brasileira de Medicina do Trabalho, v.16, n. 2, p. 128-135, 2018.

EICHINGER, F. L. F., SOARES, A. V., DE CARVALHO JÚNIOR, J. M., DA SILVA GEVAERD, M., DOMENECH, S. C., JÚNIOR, N. G. B. Dinamometria lombar: um teste funcional para o tronco. Revista Brasileira Medicina Trabalho, v.14, n. 2, p.120-126, 2016.

EKSTROM, R. A., SODERBERG, G. L., DONATELLI, R. A. Normalization procedures using maximum voluntary isometric contractions for the serratus anterior and trapezius muscles during surface EMG analysis. J Electromyogr Kinesiol. v. 15, p. 418-428, 2005.

EPAGRI - Empresa de Pesquisa Agropecuária e Extensão Rural de Santa Catarina. Síntese Anual da Agricultura de Santa Catarina 2013-2014. Empresa de Pesquisa Agropecuária e Extensão Rural de Santa Catarina/Centro de Socioeconomia e Planejamento Agrícola - Epagri/ Cepa, Florianópolis, SC, 131-139, 208p., 2015.

FAO - Food and Agriculture Organization of the United Nations - Produzir mais com menos: Mandioca. Informe de política. Um guia para a intensificação sustentável da produção, 2013. Available at: <http://www.fao.org/ag/save-and-grow/cassava/pt/> FATHALLAH, F. A, MILLER, B. J, MILES, J. A. Low back disorders in agriculture and the role of stooped work: scope, potential, interventions, and research needs. Journal of Agricultural Safety and Health. V. 14, n. 2, p. 221-245, 2008.

FATHALLAH, F. A. Musculoskeletal disorders in labor-intensive agriculture. Applied 
Ergonomics. v. 41, p. 738-743, 2010.

FERNANDES, Carlos Aparecido, DA SILVA, Douglas, PLENT, Bruna Pasquali, MERINO, Eugenio Andrés Diaz. Análise Antropométrica do Uso de uma Plantadora de Mandioca. Human Factors in Design, v.2, n.3, p 3 - 17, 2013.

FERNANDES, C. A., MANNRICH, G., MERINO, G. S. A. D., TEIXEIRA, C. S., GONTIJO, L. A., MERINO, E. A. D. Queixas musculoesqueléticas e a atividade da agricultura familiar. EFDeportes.com, Revista Digital. V. 19, n. 193, 2014.

GALLAGHER, S., MARRAS, W. S., LITSKY, A. S., BURR, D. Torso Flexion Loads and the Fatigue Failure of Human Lumbosacral Motion Segments. Spine. v. 15, n. 30(20), p. 22652273, 2005.

GALLAGHER, S., MARRAS, W. S. Tolerance of the lumbar spine to shear: A review and recommended exposure limits. Clinical Biomechanics. v. 27, p. 973-978, 2012.

GALLAGHER, S. HEBERGER, J. R. Examining the Interaction of Strength and Repetition on Musculoskeletal Disorder Risk: A Systematic Literature Review. Human Factors. V. 55, n. 1, p. 108-124, 2013.

HARBOURNE, R. KAMM, K. Upper extremity function: what's posture got to do with it? J Hand Ther. V. 28, n. 2, p. 106-113, 2015.

HERMENS, H. J., FRERIKS, B., DISSELHORST-KLUG, C., RAU, G. The SENIAM project: surface electromyography for non-invasive assessment of muscle, ISEK Congress Austria; 2002 [CD-ROM].

IBGE. Instituto Brasileiro de Geografia e Estatística. Levantamento Sistemático da Produção Agrícola (LSPA). Pesquisa Mensal de Previsão e Acompanhamento das Safras Agrícolas no Ano Civil. 113p. 2016.

JORDAN, P. W. An Introduction to Usability. London: Taylor \& Francis, 1998.

KIRKHORN, S. R., EARLE-RICHARDSON, G. BANKS, R. J. Ergonomic risks and musculoskeletal disorders in production agriculture: recommendations for effective research to practice. Journal of Agromedicine. V. 15, p. 281-299, 2010.

KRAMER, M., EBERT, V., KINZL, L., DEHNER, C., ELBEL, M., HARTWIG, E. Surface electromyography of the paravertebral muscles in patients with chronic low back pain. Arch. Phys. Med. Rehabil. V. 86, p. 31-6, 2005.

KUORINKA, I., JONSSON, B., KILBOM, A., VINTERBERG, H., BIERINGSORENSEN, F., ANDERSSON, G., et al. Standardised Nordic questionnaires for the analysis of musculoskeletal symptoms. Appl Ergon. v. 18, p. 233-237, 1987.

LARIVIÈRE, C., GRAVEL, D., ARSENAULT, A. B., GAGNON, D., LOISEL, P. Muscle recovery 
from a short fatigue test and consequence on the reliability of EMG indices of fatigue. Eur. J. Appl. Physiol. V. 89, p. 171-6, 2003.

LUTTMANN, A., JAGER, M., LAURIG, W. Electromyographical indication of muscular fatigue in occupational field studies. Int J Ind Ergon. V. 25, n. 6, p. 645-660, 2000. MERLETTI, R. Standards for reporting EMG data. Journal of Electromyography and Kinesiology. v. 7, p. 1-2, 2000.

MERINO, Giselle; SILVA, Lincoln; MATTOS, Diego; GUIMARÃES, Bruno; MERINO, Eugenio. Ergonomic evaluation of the musculoskeletal risks in a banana harvesting activity through qualitative and quantitative measures, with emphasis on motion capture (Xsens) and EMG. International Journal of Industrial Ergonomics. v. 69, p. 80-89, 2019.

MORAES, A. C., BANKOFF, A. D. P., OKANO, A. H., SIMÕES, E. C., RODRIGUES, C. E. B. Electromyographic analysis of the rectus femoris muscle during the execution of movements of the knee in leg extension machine. Revista Brasileira de Ciência e Movimento. v. 11, n. 2, p. 19-23, 2003.

MUROFUSE, N. T., MARZIALE, M. H. P. Doenças do sistema osteomuscular em trabalhadores de enfermagem. Rev Latino-am Enfermagem. v. 13, n. 3, p. 364-73, 2005. NIELSEN, J. Usabilidade na Web. Elservier, Campus, Rio de Janeiro, 2007.

SILVA, Lincoln da. Proposta de método de avaliação da força de extensão lombar por meio da dinamometria. Florianópolis, 2015. Dissertação (Mestrado) - Centro de Ciências da Saúde e do Esporte, Universidade do Estado de Santa Catarina.

O'SULLIVAN, S., SCHMITZ, T. Fisioterapia: Avaliação e Tratamento. 4 ed. São Paulo: 2004. PRAIRIE, J., PLAMONDON, A., HEGG-DELOYE, S., LAROUCHE, D., CORBEIL, P. Biomechanical risk assessment during field loading of hydraulic stretchers into ambulances. International Journal of Industrial Ergonomics. v. 54, p. 1-9, 2016.

REENEN, H. HAMBERG-VAN, H. Physical capacity in relation to low back, neck, or shoulder pain in a working population. Occupational And Environmental dicine. v. 63, n. 6, p. 371-377, 2006.

ROY, S. H., DE LUCA, C. J., CASAVANT, D. A. Lumbar muscle fatigue and chronic lower back pain. Spine. V. 14, p. 992-1001, 1989.

SANTANA, L. M. et al. Electromyographic analysis of the vertebral extensor muscles during the Biering-Sorensen Test. Motriz. V.20, n. 1. p. 112-119, 2014.

SPARTO, P. J., PARNIANPOUR, M., REINSEL, T. E., SIMON, S. Spectral and Temporal Responses of Trunk Extensor Electromyography to an Isometric Endurance Test. Spine. v. 22, p. 418-25, 1997.

STAMBOLIAN, D., ELTOUKHY, M., ASFOUR, S. Development and validation of a three dimensional dynamic biomechanical lifting model for lower back evaluation for careful box placement. International Journal of Industrial Ergonomics. v. 54, p. 10-18, 2016. 